E-ISSN : 2549-6581

Artikel Hasil Penelitian

OPEN ACCESS

Diterima : 19 Juni 2019

Direview : 4 Juli 2019

Dimuat : April 2019 - Juli 2019

\title{
Perbandingan Efektivitas Metode Brain Storming Dan Simulation Game Terhadap Peningkatan Pengetahuan Kanker Payudara Pada Siswi Kelas XII SMAN 4 Malang
}

\author{
Sri Ayu Maharani ${ }^{1 *}$, Linda Ratna Wati ${ }^{2}$, Yuseva Sariati ${ }^{3}$

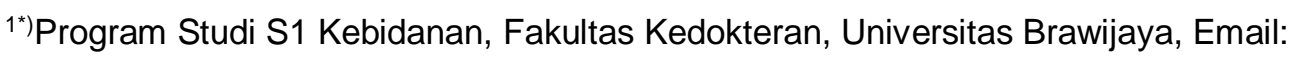 \\ sriayumaharani86@gmail.com, Tlp: +6285771700308 \\ ${ }^{2}$ Program Studi S1 Kebidanan, Fakultas Kedokteran, Universitas Brawijaya, Email: \\ linda.ratna13@gmail.com \\ ${ }^{3}$ Program Studi S1 Kebidanan, Fakultas Kedokteran, Universitas Brawijaya, Email: \\ yusevasariati@yahoo.co.id
}

\begin{abstract}
Breast cancer is a disease which has the highest prevalence rate in targeting women. One of the prevention efforts is by improving the knowledge about breast cancer as early as possible. The purpose of this research is to know the effectiveness comparison between brain storming and simulation game health promotion towards knowledge improvement about breast cancer on 12th grade students of Senior High School 4 Malang. This research used quasi-experimental design through nonequivalent control group design approach. The samples of the research were 72 12th grade students of Senior High School 4 Malang who met the inclusion criteria. The research used purposive sampling technique. In this research, questionnaires were used to collect data. The data was analyzed using Kruskal Wallis test and continued with Post Hoc test using Mann Whitney test. The post test result displayed significant differences between brain storming and simulation game groups ( $p 0,000)$ regarding the knowledge improvement about breast cancer. The conclusion of this research is that both simulation game and brain storming can improve the knowledge about breast cancer on 12th grade Senior High School 4 Malang students and simulation game method is more effective than brain storming in improving their knowledge about breast cancer.
\end{abstract}

Keywords: Health promotion, brain storming, simulation game, knowledge, breast cancer.

\begin{abstract}
ABSTRAK
Kanker payudara adalah sebuah penyakit dengan prevalensi tertinggi yang menyerang wanita. Salah satu pencegahan kanker payudara yaitu dengan meningkatkan pengetahuan mengenai kanker payudara sedini mungkin. Tujuan dari penelitian ini yaitu untuk mengetahui perbandingan efektivitas penyuluhan kesehatan antara metode brain storming dan simulation game terhadap peningkatan pengetahuan mengenai kanker payudara pada siswi kelas XII di SMAN 4 Malang. Penelitian ini menggunakan desain penelitian quasi
\end{abstract}


eksperimental dengan pendekatan non equivalent control group design. Sampel pada penelitian ini yaitu siswi kelas XII SMAN 4 yang memenuhi kriteria inklusi dan berjumlah 72 orang. Purposive sampling adalah teknik sampling yang digunakan dalam penelitian ini. Pada penelitian ini kuisioner digunakan untuk mengumpulkan data. Analisis data pada penelitian ini menggunakan uji Kruskal Wallis dan dilanjutkan dengan uji Post Hoc mnggunakan uji Mann Whitney.Hasil post test didapatkan terdapat perbedaan yang signifikan antara kelompok brain storming dan simulation game $(p 0,000)$ terkait peningkatan pengetahuan mengenai kanker payudara. Kesimpulan dari penelitian ini yaitu penyuluhan kesehatan menggunakan metode simulation game dan brain storming dapat meningkatkan pengetahuan remaja mengenai kanker payudara pada Siswi Kelas XII SMAN 4 Malang dan metode simulation game lebih efektif dibandingkan dengan brain storming dalam meningkatkan pengetahuan remaja mengenai kanker payudara.

Kata kunci : penyuluhan kesehatan, brain storming, simulation game, pengetahuan, kanker payudara

*Korespondensi: Sri Ayu Maharani. Surel: sriayumaharani86@gmail.com

\section{PENDAHULUAN}

Penyakit kanker merupakan salah satu penyebab kematian utama diseluruh dunia. Kasus baru kanker mencapai angka 14.067.894 dan jumlah kematian disebabkan oleh kanker berjumlah 8.201.575 diseluruh dunia pada tahun 2012 (GLOBOCAN, International Agency for Reasearch on Cancer). Kanker payudara merupakan penyakit kanker dengan prevalensi tertinggi setelah kanker serviks di Indonesia pada tahun 2013. Kanker payudara menempati urutan pertama di Rumah Sakit Dharmais sampai tahun 2016. ${ }^{1}$

Faktor resiko dari kanker payudara yaitu usia saat pertama kali haidyang terlalu dini yaitu kurang dari 12 tahun, wanita yang tidak menikah, wanita menikah namun belum pernah melahirkan, pertama kali melahirkan pada usia lebih dari 30 tahun, tidak pernah menyusui, penggunaan kontrasepsi hormonal atau cukup lama mendapatkan terapi yang mengandung estrogen, mengalami menopause yang terlalu lama yaitu diatas 55 tahun, riwayat kanker payudara, riwayat kanker dalam keluarga, serta merokok. ${ }^{2}$
Selain adanya faktor risiko kanker payudara, penyebab tingginya angka kematian dan kesakitan yang disebabkan oleh kanker payudara adalah sebagian besar pasien datang ke fasilitas kesehatan pada stadium lanjut sehingga pengobatan yang diberikan tidak seefektif bila pasien datang pada stadium awal. Berdasarkan hasil penelitian beberapa penyebab dari keterlambatan tersebut yaitu sebesar $47 \%$ tidak memahami mengenai kanker payudara, 14,5\% takut dioperasi, $12,5 \%$ merasa tumor tidak nyeri, 9,4\% tidak mempunyai biaya pengobatan, serta $10,2 \%$ tidak diketahui. Dikarenakan sebagian besar pasien yang menderita kanker payudara tidak memahami kanker payudara itu sendiri terutama gejala beserta cara pencegahannya. ${ }^{3}$

Pengetahuan remaja putri mengenai faktor risiko kanker payudara masih tergolong kurang, hal tersebut dinyatakan dalam penelitian Rini Mulia Sari yang berjudul "Hubungan Pengetahuan dan Sikap Dengan Risiko Kanker Payudara Pada Remaja Putri Di MAN 2 Banda Aceh". Hasil penelian tersebut menyatakan bahwa remaja yang memiliki tingkat 
pengetahuan kurang mempunyai risiko terkena kanker payudara lebih besar, yaitu sebesar $75 \%$. Maka dari itu, maka pengetahuan remaja putri mengenai kanker payudara terkait pengertian, faktor risiko, serta cara pencegahan kanker payudara perlu ditingkatkan, salah satunya melalui penyuluhan kesehatan. ${ }^{4}$

Penyuluhan kesehatan

merupakan

kegiatan

yangmemperhatikan prinsip-prinsip

belajar untuk mencapai suatu keadaan ingin hidup sehat dan mengetahui upaya yang dapat dilakukan agar terciptanya hidup yang sehat. Penyuluhan kesehatan dibagi menjadi kelompok besar, kelompok kecil dan penyuluhan massa. Kelompok besar mempunyai metode penyuluhan yaitu seminar dan ceramah, sedangkan kelompok kecil mempunyai metode penyuluhan berupa kelompok diskusi, curah pendapat, bola salju, role palay, buzz grup, serta permainan simulasi. Brain Storming (Curah pendapat) merupakan modifikasi dari metode diskusi kelompok yang mempunyai prinsip yang sama tetapi mempunyai perbedaan dimana pada permulaan diskusi berlangsung pimpinan kelompok memancing dengan sebuah permasalahan kemudian tiap peserta memberikan jawaban ataupun tanggapan dari permasalahan tersebut. Sedangkan untuk Simulation games (SIG) merupakan modifikasi dari permainan simulasi, dimana setiap anggota kelompok atau peserta akan melakukan permainan roda putar di dalamnya yang terdapat informasi mengenai kanker payudara. ${ }^{5}$

Dari studi pendahuluan yang dilakukan pada beberapa Siswi Kelas XII SMAN 4 Kota Malang didapatkan hasil sebagian besar pengetahuan mengenai kanker payudara masih kurang terutama pada point faktor risiko, gejala dan tanda, serta pencegahan yang dapat dilakukan terkait kanker payudara. Dan seluruh siswi yang mengisi kuisioner tersebut belum pernah mendapatkan penyuluhan mengenai kanker payudara dengan metode simulation game maupun brainstorming.

\section{METODE PENELITIAN Lokasi dan Rancangan Penelitian}

Penelitian ini dilaksanakan di SMAN 4 Kota Malang, pemilihan lokasi ini didasari oleh hasil studi pendahuluan yang dilakukan. Penelitian ini menggunakan desain penelitian Quasy Eksperimental dengan pendekatan Nonequivalent Control Group Design.

\section{Populasi dan sampel}

Populasi pada penelitian ini adalah seluruh Siswi SMAN 4 Malang Kelas XII Tahun Ajaran 2018/2019 yang berjumlah 168 orang. Sampel pada penelitian ini adalah Siswi Kelas XII SMAN 4 Malang yang memenuhi kriteria inkusi. Pada penelitian ini menggunakan 3 perlakuan sehingga membutuhkan 3 kelompok, sehingga total sampel berjumlah 72 siswi. Pada penelitian ini teknik sampling yang digunakan yaitu teknik purposive sampling dengan memperhatikan kriteria inklusi dan ekslusi. Kriteria Inklusi pada penelitian ini yaitu siswi kelas XII SMAN 4 yang hadir dalam rangkaian acara penyuluhan kesehatan dengan metode simulation game dan metode brain storming dan bersedia menjadi responden, sedangkan kriteria ekslusi meliputi siswi yang pernah mengikuti penyuluhan kesehatan mengenai kanker payudara dan siswi yang tidak lengkap dalam mengisi kuisioner pre test dan post test.

\section{Metode Pengumpulan data}

Metode pengumpulan data pada penelitian ini berupa lembar observasi berupa kuisioner yang 
diberikan pada saat sebelum penyuluhan kesehatan (pre test) dan setelah penyuluhan kesehatan di hari yang sama (post test) yang berisi 30 pertanyaan yang dapat mengukur tingkat pengetahuan responden mengenai kanker payudara.

\section{Analisis Data \\ Analisa Univariat}

Analisis univariat dilakukan untuk mendapatkan gambaran tentang distribusi frekuensi responden serta gambaran pada setiap variabel dependen dan disajikan dalam bentuk tabel. Distribusi frekuensi pada penelitian ini meliputi tabel distribusi frekuensi tingkat pengetahuanresponden sebelum diberikan penyuluhan kesehatan, tabel distribusi frekuensi tingkat pengetahuan responden setelah diberikan penyuluhan kesehatan, tabel distribusi frekuensi perbandingan efektivitas antara kelompok brain storming, simulation games, dan kontrol, serta tabel distribusi frekuensi perbandingan efektivitas penyuluhan kesehatan antara metode brain storming dan simulation game.

\section{Analisis Multivariat}

Analisa yang digunakan terhadap lebih dari dua variabel independen adalah analisa multivariat (Notoadmodjo, 2010). Sebelum dilakukannya uji statistik, maka dilakukan uji normalitas terlebih dahulu menggunakan kolmogrov smirnov. Pada penelitian ini data tidak terdistribusi secara normal dikarenakan $p$ value $<0,05$, sehingga uji statistik yang digunakan adalah uji kruskal wallis.

\footnotetext{
Uji Kruskal Wallis yang berfungsi untuk menentukan perbedaan signifikasi secara statistik antara dua atau lebih kelompok variabel independen terhadap variabel
}

dependen yang berskala data numerik dan ordinal.

Adapun hipotesis pada uji Kruskal Wallis yaitu $\mathrm{HO}$ (tidak ada perbedaan efektivitas yang bermakna antara metode simulation, brain storming dan kontrol terhadap peningkatan pengetahuan siswi). Sedangkan $\mathrm{H} 1$ yaitu (ada perbedaan efektivitas yang bermakna antara metode simulation game, brain storming, dan kontrol terhadap peningkatan pengetahuan siswi)

Adapun kriteria uji tolak hipotesis $(\mathrm{H} 0)$ jika nilai signifikasi $p$ value $(>0,05)$. Dan hipotesis diterima (H1) apabila nilai signifikasi $p$-value $(<$ $0,05)$.

Adapun bila hipotesis diterima (H1), maka dilanjutkan dengan uji Post Hoc menggunakan uji Mann Whitney yang bertujuan untuk membandingkan perbedaan signifikasi antarakelompok brain storming dan simulation game. Adapun hipotesis pada uji Mann Whitney yaitu $\mathrm{HO}$ (tidak ada perbedaan efektivitas yang bermakna antara metode simulation game dan brain storming). Sedangkan $\mathrm{H} 1$ yaitu (ada perbedaan efektivitas yang bermakna antara metode simulation game dan brain storming). Adapun kriteria uji tolak hipotesis $(\mathrm{H} 0)$ jika nilai signifikasi p-value (> 0,05). Dan hipotests diterima $(\mathrm{H} 1)$ apabila nilai signifikasi $\mathrm{p}$ value $(<0,05)$.

\section{HASIL PENELITIAN}

\section{Gambaran Umum Lokasi Penelitian}

Penelitian ini dilaksanakan di SMAN 4 Kota Malang yang berada di jalan Tugu Utara No. 1, Malang, Jawa Timur. Sekolah ini mempunyai visi yaitu unggul dalam IMTAQ, IPTEK, berwawasan lingkungan, dan berpijak pada budaya bangsa, serta berdaya saing tinggi. SMAN 4 mempunyai sarana dan prasarana yang baik untuk 
memenuhi kebutuhan peserta didik dalam proses pembelajaran.

\section{Tingkat Pengetahuan Siswi Terhadap Kanker Payudara Sebelum Mendapatkan Penyuluhan Kesehatan Menggunakan Metode Brain storming dan Simulation game}

$$
\text { Data dibawah ini }
$$
mendeskripsikan hasil karakteristik dari variabel penelitian yaitutingkat pengetahuan siswi sebelum (pre test) dilakukan penyuluhan kesehatan mengenai kanker payudara dengan metode brain storming dan simulation game. Hasil tersebut disajikan dalam bentuk tabel sebagai berikut:

\section{Tabel 5.1 Distribusi Tingkat} Pengetahuan Responden Tentang Kanker Payudara Sebelum Diberikan Penyuluhan Kesehatan

\begin{tabular}{|c|c|c|c|c|c|c|c|c|}
\hline \multirow{3}{*}{$\begin{array}{l}\text { Metode } \\
\text { Penyuluhan } \\
\text { Kesehatan }\end{array}$} & \multicolumn{8}{|c|}{ Tingkat Pengetahuan (pre test) } \\
\hline & \multicolumn{2}{|c|}{ Baik } & \multicolumn{2}{|c|}{ Cukup } & \multicolumn{2}{|c|}{$\begin{array}{l}\text { Kuran } \\
\text { g }\end{array}$} & \multicolumn{2}{|c|}{ Total } \\
\hline & $\mathbf{N}$ & $\%$ & $\mathbf{N}$ & $\%$ & $\mathbf{N}$ & $\%$ & $\mathbf{N}$ & $\%$ \\
\hline $\begin{array}{l}\text { Brain } \\
\text { storming }\end{array}$ & 5 & 6,9 & 19 & 26,4 & 0 & 0 & $\begin{array}{l}2 \\
4\end{array}$ & 33,3 \\
\hline $\begin{array}{l}\text { Simulation } \\
\text { game }\end{array}$ & 11 & 15,3 & 9 & 12,5 & 4 & 5,6 & $\begin{array}{l}2 \\
4\end{array}$ & 33,3 \\
\hline Kontrol & 12 & 16,7 & 11 & 15,3 & 1 & 1,4 & $\begin{array}{l}2 \\
4 \\
\end{array}$ & 33,4 \\
\hline Total & 28 & 38,9 & 39 & 54,2 & 5 & 7 & $\begin{array}{l}7 \\
2\end{array}$ & 100 \\
\hline
\end{tabular}

\begin{abstract}
Berdasarkan tabel 5.1 dapat diinterpretasikan bahwa tingkat pengetahuan responden sebelum diberikan penyuluhan kesehatan (pre test) sebagian besar memiliki tingkat pengetahuan cukup sebanyak 39 siswi (54,17\%), pengetahuan baik sebanyak 28 siswi $(38,89 \%)$, serta
\end{abstract}

berpengetahuan kurang sebanyak 5 siswi (6,95\%). Pada kelompok brain storming sebagian besar responden memiliki tingkat pengetahuan cukup sebanyak 19 siswi, tingkat pengetahuan baik 5 siswi, dan tidak ada yang berpengetahuan kurang. Pada kelompok simulation game sebagian besar responden memiliki tingkat pengetahuan baik sebanyak 11 siswi, tingkat pengetahuan cukup 9 siswi, dan tingkat pengetahuan kurang 4 siswi. Kelompok kontrol sebagian besar memiliki tingkat pengetahuan baik sebanyak 12 siswi, pengetahuan cukup 11 siswi, dan pengetahuan kurang 1 siswi.

Tingkat Pengetahuan Siswi Terhadap Kanker Payudara Sesudah Mendapatkan Penyuluhan Kesehatan Menggunakan Metode Brain Storming dan Simulation Game

Data dibawah ini mendeskripsikan hasil karakteristik dari variabel penelitian yaitu tingkat pengetahuan siswi sesudah (post test) dilakukan penyuluhan kesehatan mengenai kanker payudara dengan metode brain storming dan simulation game. Hasil tersebut disajikan dalam bentuk tabel sebagai berikut: 


\begin{tabular}{|c|c|c|c|c|c|c|c|c|}
\hline $\begin{array}{l}\text { Tabel } \\
\text { Pengetah } \\
\text { Kanker } \\
\text { Diberikan }\end{array}$ & 5 & $\begin{array}{r}\text { } \\
\text { n R } \\
\text { Pay } \\
\text { enyu }\end{array}$ & $\begin{array}{l}\text { esp } \\
\text { uda }\end{array}$ & $\begin{array}{l}\text { bus } \\
\text { onde } \\
\text { a } \\
\text { n Ke }\end{array}$ & & nte & & \\
\hline Metode & & ingka & & $\begin{array}{l}\text { ngetal } \\
\text { test) }\end{array}$ & uar & & & Total \\
\hline n & & Baik & & ukup & K & rang & & \\
\hline Kesehatan & $\mathbf{N}$ & $\%$ & $\mathbf{N}$ & $\%$ & $\mathbf{N}$ & $\%$ & $\mathbf{N}$ & $\%$ \\
\hline Post test & & & & & & & & \\
\hline $\begin{array}{l}\text { Brain } \\
\text { storming }\end{array}$ & 15 & 20,8 & 9 & 12,5 & 0 & 0 & 24 & 33,3 \\
\hline $\begin{array}{l}\text { Simulation } \\
\text { game }\end{array}$ & 24 & 33.3 & 0 & 0 & 0 & 0 & 24 & 33,3 \\
\hline Kontrol & 12 & 16,7 & 12 & 16,7 & 0 & 0 & 24 & 33,3 \\
\hline Total & 51 & 70,8 & 21 & 29,2 & 0 & 0 & 72 & 100 \\
\hline
\end{tabular}

responden memiliki tingkat pengetahuan baik sebanyak 15 siswi $(20,83 \%)$, tingkat pengetahuan cukup sebanyak 9 siswi (12,5\%), serta tidak ada responden dengan tingkat pengetahuan kurang. Pada kelompok simulation game seluruh responden memiliki tingkat pengetahuan baik yaitu 24 siswi (33,33\%), sedangkan untuk kelompok kontrol tingkat pengetahuan baik dan cukup sebanyak 12 siswi, dan tidak ada responden dengan tingkat pengetahuan kurang.

\section{Berdasarkan tabel $\quad 5.3$}

Tabel 5.3 Distribusi Tingkat

Pengetahuan Responden Tentang Kanker Payudara Sebelum dan Sesudah Diberikan Penyuluhan Kesehatan

\begin{tabular}{|c|c|c|c|c|c|c|}
\hline \multirow{3}{*}{$\begin{array}{c}\text { Metode } \\
\text { Penyuluh } \\
\text { an }\end{array}$} & \multicolumn{6}{|c|}{ Tingkat pengetahuan } \\
\hline & \multicolumn{3}{|c|}{ Pre test } & \multicolumn{3}{|c|}{ Post test } \\
\hline & Baik & cukup & Kurang & Baik & cukup & Kurang \\
\hline $\begin{array}{l}\text { Brain } \\
\text { storming }\end{array}$ & 5 & 19 & 0 & 15 & 9 & 0 \\
\hline $\begin{array}{l}\text { Simulatio } \\
\text { n game }\end{array}$ & 11 & 9 & 4 & 24 & 0 & 0 \\
\hline Kontrol & 12 & 11 & 1 & 12 & 12 & 0 \\
\hline Total & 28 & 39 & 5 & 51 & 21 & 0 \\
\hline
\end{tabular}

Berdasarkan tabel 5.2 dapat diinterpretasikan bahwa tingkat pengetahuan responden setelah mendapatkan penyuluhan kesehatan (post test) adalah sebagian besar memiliki tingkat pengetahuan baik sebanyak 51 siswi $(70,83 \%)$, tingkat pengetahuan cukup sebanyak 21 siswi, dan tidak ada yang memiliki tingkat pengetahuan kurang. Pada penyuluhan kesehatan dengan metode brain storming sebagian besar peningkatan kelompok brain storming pada pre test ke post test sebesar 10 siswi pada tingkat pengetahuan baik, serta penurunan pada tingkat pengetahuan cukup sebesar 10 siswi, sedangkan peningkatan kelompok brain storming pada pre test ke post test 2 sebesar 16 siswi pada tingkat pengetahuan baik, dan terjadi penurunan pada tingkat pengetahuan cukup sebesar 16 siswi. Peningkatan kelompok simulation game pada pre test ke post test sebesar 13 siswi pada tingkat pengetahuan baik, serta penurunan pada tingkat pengetahuan cukup dan kurang. Penurunan sebesar 9 siswi pada pengetahuan cukup, dan 4 siswi pada pengetahuan kurang. Perubahan tingkat pengetahuan kelompok kontrol pada saat pre test ke post test yaitu terjadi peningkatan pengetahuan cukup sebanyak 1 siswi, dan penurunan pada tingkat pengetahuan kurang sebanyak 1 siswi, dan tingkat pengetahuan baik tetap berjumlah 12 siswi. 
Analisis Perbandingan Efektivitas Penyuluhan Kesehatan Terhadap Peningkatan Pengetahuan Siswi Mengenai Kanker Payudara

Sebelum menentukan uji
statistik yang digunakan pada
penelitian ini, maka data diuji
normalitas terlebih dahulu
menggunakan uji kolmogrof smirnov
dan hasil uji normalitas menyatakan
bahwa data berdistribusi tidak normal
( $p$-value < 0,05). Seluruh uji statistik
dilakukan dengan bantuan SPSS versi
20.0 for windows.

Berdasarkan hal tersebut maka uji statistik yang digunakan dalam penelitian ini adalah Uji Kruskall Waillis yang bertujuan untuk mengetahui perbandingan efektivitas penyuluhan kesehatan antara kelompok brain storming, simulation game, dan kelompok kontrol. H0 ditolak apabila z hitung $>z$ tabel dan $p$ value $<0,05$, sedangkan z HO diterima apabila $\mathrm{z}$ hitung $\leq z$ tabel dan $p$ value $>0,05$.

\section{Tabel 5.4 Hasil Perbandingan} Efektivitas Penyuluhan Kesehatan Antara Metode Brain Storming, Simulation Game, dan Kontrol

\begin{tabular}{lcc}
\hline & $\mathrm{p}$ Value & Keterangan \\
\hline Pre & 0,504 & Tidak \\
Post & 0,000 & signifikan \\
test & & Signifikan
\end{tabular}

Pada tabel 5.4 menunjukkan bahwa nilai signifikasi $p$ value pre test adalah 0,504. Dari hasil tersebut dapat diketahui bahwa nilai $p$ value $>0,05$ $(0,504>0,05)$ yang artinya tidak terdapat perbedaan tingkat pengetahuan yang signifikan sebelum diberikan penyuluhan kesehatan antara kelompok brain storming, simulation game, dan kontrol. Hasil post test menunjukkan nilai signifikasi $p$ value sebesar 0,000 . Dari hasil tersebut dapat diketahui bahwa nilai $p$ value $<0,05 \quad(0,000<0,05)$ yang artinya terdapat perbedaan yang signifikan antara kelompok brain storming, simulation game, dan kontrol.

\section{Analisis Perbandingan Efektivitas}

Penyuluhan Kesehatan

Menggunakan Metode Brain storming dan Simulation game Terhadap Peningkatan Pengetahuan Siswi Mengenai Kanker Payudara

Hasil yang didapatkan setelah dilakukan uji statistik menggunakan Kruskal Wallis adalah terdapat perbedaan yang signifikan antara kelompok brain storming, simulation game, dan kontrol. Berdasarkan hal tersebut maka dilanjutkan dengan melakukan uji Pos Hoc menggunakan uji Mann Whitney untuk menganalisis perbedaan efektifitas penyuluhan kesehatan menggunakan metode brain storming dan simulation game terhadap peningkatan pengetahuan siswi. Dapat diketahui bahwa $\mathrm{HO}$ ditolak apabila $z$ hitung $>\mathrm{z}$ tabel dan $\mathrm{p}$ value $<0,05$,

sedangkan z HO diterima apabila $\mathrm{z}$ hitung $\leq z$ tabel dan $p$ value $>0,05$. 
Tabel 5.5 Hasil Perbandingan Efektivitas Metode Brain storming Dan Simulation game

\begin{tabular}{|c|c|c|c|c|}
\hline Kelompok & Z & $\begin{array}{c}P \\
\text { value }\end{array}$ & $\begin{array}{l}\text { Mean } \\
\text { Rank }\end{array}$ & $\begin{array}{c}\text { Keterang } \\
\text { an }\end{array}$ \\
\hline $\begin{array}{l}\text { Brain } \\
\text { storming }\end{array}$ & $-3,12$ & 0,755 & $\begin{array}{l}23,88 \\
25,13\end{array}$ & $\begin{array}{l}\text { Tidak } \\
\text { signifikan }\end{array}$ \\
\hline $\begin{array}{l}\text { Simulatio } \\
\text { n game }\end{array}$ & $-5,20$ & 0,000 & $\begin{array}{r}14,5 \\
34,85\end{array}$ & $\begin{array}{c}\text { Signifika } \\
n\end{array}$ \\
\hline
\end{tabular}

Pada tabel 5.5 menunjukkan bahwa nilai signifikasi $\mathrm{p}$ Asymp. Sig. (2-tailed) pre test adalah 0,755 . Dari hasil diatas dapat diketahui bahwa nilai $\mathrm{p}$ Asymp. Sig (2-tailed) $>0,05$ $(0,755>0,005)$ yang artinya tidak terdapat perbedaan tingkat pengetahuan yang signifikan sebelum diberikan penyuluhan kesehatan antara kelompok penyuluhan kesehatan menggunakan metode brain storming dan simulation game. Sedangkan hasil post test menunjukan p Asymp. Sig (2-tailed) adalah 0,000. Dari hasil tersebut dapat diketahui bahwa nilai $p$ Asymp. Sig (2-tailed) < $0,05(0,000<0,05)$ yang artinya terdapat perbedaan yang signifikan antara kelompok penyuluhan kesehatan menggunaan metode brain storming dan simulation game. Hal ini berarti bahwa metode simulation game lebih efektif dibandingkan dengan metode brain storming dalam peningkatan pengetahuan siswi mengenai kanker payudara.

\section{PEMBAHASAN}

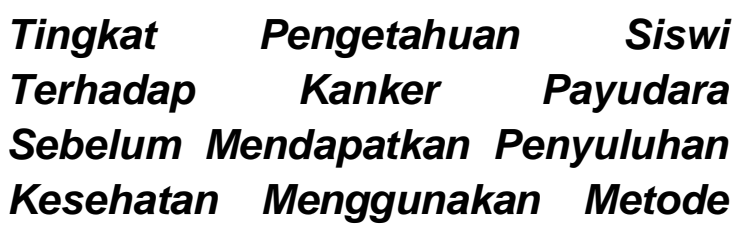

\section{Brain Storming dan Simulation Game}

$\begin{array}{cc}\text { Tingkat } & \text { pengetahuan } \\ \text { responden sebelum mendapatkan }\end{array}$ penyuluhan kesehatan sebagian besar memiliki tingkat pengetahuan cukup yaitu 39 siswi, kemudian tingkat pengetahuan baik 28 siswi, dan tingkat pengetahuan kurang 5 siswi. Pada kelompok kontrol terdapat siswi yang berpengetahuan kurang, sedangkan pada kelompok brain storming tidak terdapat siswi yang berpengetahuan kurang.

Hal yang menyebabkan sebagian besar siswi memiliki tingkat pengetahuan cukup dan terdapat siswi yang berpengetahuan kurang yaitu dimungkinkan karena responden belum pernah mendapatkan penyuluhan kesehatan mengenai kanker payudara. Sumber informasi yang didapatkan dari penyuluhan kesehatan dapat mempengaruhi pengetahuan seseorang, hal tersebut sejalan dengan yang dijelaskan Notoadmodjo bahwa pengetahuan adalah hasil tahu, yang dapat diperoleh dari penyuluhan kesehatan. ${ }^{6}$ Teori tersebut di dukung oleh hasil penelitian Oki yang berjudul "Pengaruh Pendidikan Kesehatan Tentang Pencegahan Kanker Payudara

Terhadap Peningkatan Pengetahuan Dan Sikap Wanita Usia Produktif di Desa Sumur Musuk Boyolali" bahwa peningkatan pengetahuan mengenai pencegahan kanker payudara pada wanita usia subur terjadi setelah diberikan penyuluhan kesehatan. ${ }^{7}$

Pada hasil penelitian didapatkan perbedaan jumlah siswi yang memiliki tingkat pengetahuan 
kurang pada ketiga kelompok. Hal tersebut dapat dipengaruhi oleh kesadaran dalam mengakses informasi yang berkaitan dengan kanker payudara, sehingga tinggi rendahnya kesadaran dalam mengakses informasi mengenai kanker payudara dapat mempengaruhi tingkat pengetahuan seseorang. Hal ini di dukung oleh hasil penelitian Vitro, Rizanda, dan Yenita yang berjudul "Faktor-Faktor Yang Berhubungan Dengan Tingkat Pengetahuan Wanita Usia Subur Tentang SADARI Di Nagari Painan" bahwa wanita usia subur yang terpapar informasi memiliki pengetahuan yang lebih tinggi dibandingkan dengan yang tidak terpapar informasi. ${ }^{8}$ Sehingga semakin sering seseorang mencari informasi mengenai kanker payudara, maka semakin tinggi tingkat pengetahuan yang dimilikinya.

Selain kesadaran dalam mengakses informasi, salah satu faktor yang mempengaruhi tingkat pengetahuan seseorang yaitu kemudahan dalam mendapatkan informasi. Hal ini sesuai dengan yang dijelaskan Notoadmodjo, $S$ bahwa pengetahuan seorang individu dipengaruhi oleh tinggi rendahnya perkembangan informasi mengenai sesuatu di lingkungannya. ${ }^{9}$ Semakin berkembangnya informasi mengenai kanker payudara di lingkungan remaja, maka akan semakin banyak informasi yang diperoleh, sehingga tingkat pengetahuan remaja mengenai kanker payudara dapat meningkat. Sehingga kemudahan seseorang dalam memperoleh informasi dapat mempercepat seseorang memperoleh pengetahuan yang baru. ${ }^{10}$
Kemudahan dalam mencari informasi dapat diperoleh remaja dengan menggunakan media massa, termasuk mencari informasi mengenai kanker payudara. Hal tersebut dikarenakan media yang digunakan untuk mencari informasi dapat mempengaruhi pengetahuan seseorang. Hal tersebut di dukung oleh hasil penelitian Ratna Indriana yang menyatakan bahwa terdapat hubungan jenis media massa dengan pengetahuan remaja mengenai kesehatan reproduksi. ${ }^{11}$ Jenis media massa (cetak maupun elektronik) berperan penting untuk memberikan informasi tentang pengetahuan kesehatan. Perkembangan teknologi saat ini membuat remaja mudah menggunakan media massa untuk mengakses suatu informasi, sehingga semakin banyak jenis media massa yang digunakan, maka semakin banyak pengetahuan mengenai kanker payudara yang dapat diperoleh.

Sehingga dapat disimpulkan bahwa sumber informasi yang diperoleh dari berbagai media maupun penyuluhan kesehatan dapat mempengaruhi tingkat pengetahuan remaja mengenai kanker payudara.

\section{Tingkat Pengetahuan Siswi Terhadap Kanker Payudara Sesudah Mendapatkan Penyuluhan Kesehatan Menggunakan Metode Brain Storming dan Simulation Game}

Tingkat
responden setelah mendapatkan
penyuluhan kesehatan (post test)
mengalami peningkatan jumlah tingkat
pengetahuan baik. Hal ini dipengaruhi
oleh adanya penambahan informasi


yang didapatkan dari penyuluhan kesehatan pada kelompok brain storming dan simulation game, sehingga dapat meningkatkan pengetahuan dan responden mengenai kanker payudara secara signifikan. Hal tersebut sejalan dengan yang dijelaskan oleh Notoadmodjo bahwa penyuluhan kesehatan merupakan kegiatan yang dilakukan untuk meningkatkan pengetahuan agar terjadi perubahan derajat kesehatan individu/kelompok ke arah yang lebih baik. ${ }^{12}$

Hasil penelitian ini di dukung oleh penelitian yang dilakukan oleh Laras yang berjudul "Efektifitas Pendidikan Kesehatan Terhadap Nilai Pengetahuan Mengenai SADARI Pada Remaja Putri di SMPN 3 Tangerang Selatan" yanng menyatakan bahwa pendidikan kesehatan memiliki efektifitas yang tinggi dalam meningkatkan nilai pengetahuan remaja putri mengenai SADARI. ${ }^{13}$ Sehingga salah satu faktor yang meningkatkan pengetahuan seseorang adalah dengan mengikuti penyuluhan kesehatan sehingga informasi yang dimiliki dapat bertambah dan pengetahuan dapat meningkat.

Keberhasilan penyuluhan kesehatan pada penelitian ini di pengaruhi oleh metode yang sesuai dengan besarnya kelompok sasaran sehingga proses penyelenggaraan yang dilakukan pada saat penyuluhan kesehatan dapat lebih meningkatkan ketertarikan remaja dalam mengikuti penyuluhan. Metode yang digunakan yaitu brain storming dan simulation game yang merupakan kelompok kecil dengan jumlah peserta di setiap kelompoknya $<15$ siswi. ${ }^{14}$ Kegiatan yang dilakukan menggunakan metode brain storming adalah diskusi kelompok yang mengharuskan setiap anggota kelompok mengeluarkan pendapatnya masing-masing mengenai permasalahan yang terdapat pada kasus brain storming tersebut, sedangkan kegiatan yang dilakukan pada kelompok simulation game adalah memainkan roda putar yang berisi pertanyaan yang harus dijawab setiap anggota kelompok sehingga membangkitkan motivasi untuk berkompetitif setiap kelompok tersebut.

Kedua metode tersebut dapat meningkatkan pengetahuan remaja dikarenakan terdapat proses berfikir dan bertukar informasi yang terjadi pada saat penyuluhan kesehatan. Hal ini sejalan dengan hasil penelitian yang dilakukan oleh Andi, Buraerah, dan Muliani yang berjudul "Pengaruh Metode Simulasi Permainan dan Brain storming Terhadap Pengetahuan dan Sikap Pengurus PKI-R SMA Tentang Kesehatan Reproduksi Remaja Di Kota Makasar" menyatakan bahwa terjadi peningkatan pengetahuan dan sikap remaja mengenai kesehatan reproduksi setelah diberikan penyuluhan menggunakan metode brain storming dan permainan simulasi, hal tersebut dipengaruhi oleh proses penyelenggaraan metode brain storming dan permainan simulasi pada saat penyuluhan kesehatan dapat menumbuhkan rasa nyaman sehingga peserta lebih mudah dalam menerima materi. ${ }^{15}$

Pada saat pelaksanaan penyuluhan kesehatan membutuhkan teknik komunikasi yang tepat, 
dikarenakan teknik komunikasi merupakan faktor keberhasilan dalam penyuluhan kesehatan. Teknik komunikasi yang digunakan dalam kelompok brain storming dan simulation game adalah teknik komunikasi secara langsung, dikarenakan penyuluh langsung bertatap muka dengan peserta penyuluhan. ${ }^{16}$

Pada kelompok brain storming penyuluh langsung berhadapan secara tatap muka dengan sasaran pada saat mengawasi jalannya diskusi dan penyampaian kesimpulan di akhir diskusi. Pada kelompok simulation game, penyuluh menyampaikan pesannya dibantu dengan media roda putar yang berisi pertanyaan mengenai kanker payudara secara langsung. Di dalam roda putar tersebut hanya berisi pertanyaan untuk menstimulasi peserta untuk berfikir terkait jawaban yang tepat tentang kanker payudara, tetapi penyuluh tetap memberikan informasi mengenai kanker payudara apabila jawaban dari peserta kurang tepat atau bila peserta tidak dapat menjawab pertanyaan pada roda putar tersebut. Teknik komunikasi yang dilakukan secara langsung dapat meningkatkan minat seseorang dalam menerima informasi dikarenakan terjadi komunikasi dua arah dan memberikan kesempatan kepada peserta untuk bertanya maupun berpendapat sehingga penyuluhan kesehatan menjadi lebih menarik.

Dapat disimpulkan bahwa pemberian penyuluhan kesehatan secara efektif dapat meningkatkan pengetahuan remaja mengenai kanker payudara. Metode penyuluhan, prosedur pelaksanaan, serta teknik komunikasi adalah faktor yang mempengaruhi keberhasilan penyuluhan kesehatan.

Hasil post test menyatakan bahwa pada kelompok kontrol terdapat 1 (satu) siswi mengalami peningkatan pengetahuan dari tingkat pengetahuan kurang menjadi tingkat pengetahuan cukup. Hal tersebut dikarenakan adanya proses belajar yang terjadi pada saat mengisi lembar pre test dan post test. Lembar pre test dan post test berisikan pernyataan mengenai kanker payudara yang dapat memberikan informasi secara tidak langsung kepada responden. Informasi tersebut diperoleh dari pengulangan dan pengkodean (coding) pada saat pengisian lembar pre test dan post test - Pengulangan merupakan repitisi terhadap informasi yang dilakukan secara terus menerus hingga informasi tersebut berhasil dipelajari. Sedangkan pengkodean (coding) merupakan suatu proses belajar yang menempatkan informasi agar dapat diingat dengan menggunakan kalimat yang di anggap memonic. Informasi yang diperoleh pada kelompok kontrol disimpan dalam ingatan jangka pendek dan hanya bertahan 20-30 detik serta membutuhkan pengulangan pemberian informasi sehinga informasi dapat disimpan di memori jangka panjang. ${ }^{17}$ Namun, pada kelompok kontrol tidak terjadi pengulangan pemberian informasi, sehingga informasi yang di dapatkan tidak bertahan lama.

Sehingga dapat disimpulkan bahwa hasil yang diperoleh dari pemberian penyuluhan kesehatan lebih signifikan dalam meningkatkan 
pengetahuan remaja mengenai kanker payudara dibandingkan dengan kelompok kontrol. Hal tersebut dikarenakan adanya penambahan dan pengulangan informasi yang diperoleh pada saat penyuluhan kesehatan.

\section{Analisis Perbandingan Efektivitas} Penyuluhan Kesehatan Antara Metode Brain Storming dan Simulation Game Terhadap Peningkatan Pengetahuan Siswi Mengenai Kanker Payudara

Hasil yang didapatkan setelah dilakukan uji statistik menggunakan Kruskal Wallis adalah terdapat perbedaan yang signifikan antara kelompok brain storming, simulation game, dan kontrol. Berdasarkan hal tersebut maka dilanjutkan dengan melakukan uji Pos Hoc menggunakan uji Mann Whitney dan diperoleh hasil yaitu terdapat perbedaan yang signifikan antara metode brain storming dan simulation game setelah diberikan penyuluhan kesehatan.

Kedua metode tersebut efektif dalam meningkatkan pengetahuan siswi mengenai kanker payudara, namun berdasarkan hasil post test metode simulation game lebih efektif dalam peningkatkan pengetahuan remaja dibandingkan dengan metode brain storming.

Keberhasilan penyuluhan kesehatan menggunakan metode simulation game dipengaruhi oleh beberapa faktor, diantaranya yaitu penggunaan media penyuluhan kesehatan, prosedur pelaksanaan penyuluhan, serta kecerdasan responden.

Salah satu faktor yang
mempengaruhi

pengetahuan siswi pada kelompok simulation game adalah penggunaan alat bantu pada saat penyuluhan kesehatan yang berupa roda putar. Hal tersebut sejalan dengan yang dijelaskan oleh Notoadmodjo bahwa alat bantu disebut media penyuluhan kesehatan yang berguna untuk mempermudah peserta dalam menerima informasi yang disampaikan oleh penyuluh. ${ }^{18}$

Alat bantu yang digunakan dalam penelitian ini berupa roda putar yang berisikan 10 pertanyaan yang dapat menstimulasi responden untuk berdiskusi terkait pertanyaan mengenai kanker payudara. Kemudian kelompok lain mendengarkan jawaban dari kelompok yang menjawab, sehingga ada kegiatan bertukar informasi pada metode ini.

Saat memainkan roda putar indra yang digunakan adalah mata dan telinga sehingga mempermudah responden dalam mencerna informasi yang diterima pada saat penyuluhan. Hal ini sejalan dengan yang dijelaskan oleh Notoadmodjo bahwa pengetahuan diperoleh sebagian besar oleh indra pengelihatan $(30 \%)$ dan indra pendengaran $(10 \%) .{ }^{19}$ Semua panca indra merupakan jalur penerimaan informasi ke otak, semakin banyak indra yang di stimulasi pada saat penyampaian informasi maka akan semakin banyak informasi yang diterima dan disimpan. Selain hal tersebut, metode tertulis (bacaan) dapat meningkatkan kemampuan seseorang untuk mengingat informasi secara lebih baik, dikarenakan dengan membaca kemampuan mengingat akan meningkat $72 \%$ sesudah 3 jam. ${ }^{20} \mathrm{Pada}$ 
permainan roda putar ini responden membaca pertanyaan yang ada dalam roda tersebut, sehingga akan meningkatkan kemampuan responden dalam mengingat pertanyaan yang berhubungan dengan kanker payudara yang memudahkan responden dalam mengenali soal-soal pada saat post test.

Berdasarkan hal tersebut,
dengan menggunakan media
penyuluhan yang melibatkan indra pengelihatan dan pendengaran dalam metode simulation game dapat mempermudah responden untuk mencerna informasi secara lebih baik dibandingkan dengan metode brain storming.

Pada metode simulation game peserta harus mengumpulkan poin sebanyak banyaknya dengan menjawab pertanyaan dengan benar, sehingga dapat meningkatkan jiwa kompetitif peserta dalam memainkan roda putar. Hal tersebut merupakan kelebihan pada metode simulation game yaitu dapat menumbuhkan jiwa kompetitif dan dapat meningkatkan motivasi peserta dalam memperoleh informasi sehingga peserta akan lebih tertarik dan antusias dalam mengikuti penyuluhan kesehatan mengenai kanker payudara dibandingkan dengan metode brain storming dikarenakan pada prosedurnya mengharuskan seluruh peserta untuk berpendapat sehingga semua peserta memiliki hak yang sama sehingga tidak meningkatkan jiwa kompetitif peserta penyuluhan. ${ }^{21}$

Hasil post test menunjukkan bahwa terjadi penurunan Mean Rank pada kelompok brain storming, akan tetapi terjadi peningkatan pengetahuan setelah dilakukannya penyuluhan kesehatan. Hal tersebut tidak mempengaruhi hasil peningkatan pengetahuan pada kelompok brain storming, dikarenakan mean rank hanya merupakan rata-rata peringkat pada suatu kelompok yang digunakan untuk membandingkan signifikasi dari kedua kelompok yang di ujikan. ${ }^{22}$

Sehingga dapat disimpulkan bahwa setelah dilakukan uji Mann Whitney dengan membandingkan mean rank pada kedua kelompok, diperoleh hasil bahwa penyuluhan kesehatan mengunakan metode simulation game lebih efektif dibandingkan metode brain storming. $\mathrm{Hal}$ tersebut dipengaruhi oleh penggunaan media/alat bantu dan prosedur pelaksanaan penyuluhan.

\section{SIMPULAN}

Berdasarkan hasil analisa dan pembahasan dalam penelitian tentang "Perbandingan Efektivitas Penyuluhan Kesehatan Antara Metode Brain Storming dan Simulation Game Terhadap Tingkat Pengetahuan Mengenai Kanker Payudara Siswi Kelas XII SMAN 4 Kota Malang". Sehingga dapat disimpulkan:

1. Metode simulation game lebih efektif dalam meningkatkan pengetahuan remaja mengenai kanker payudara dibandingkan dengan metode brain storming.

2. Tingkat pengetahuan siswi sebelum mendapatkan penyuluhan kesehatan menggunakan metode brain storming dan simulation game sebagian besar memiliki tingkat pengetahuan cukup sebanyak 39 siswi $(54,17 \%)$, tingkat 
pengetahuan baik sebanyak 28 siswi $\quad(38,89 \%)$, tingkat pengetahuan kurang sebanyak 5 siswi (6.95\%).

3. Tingkat pengetahuan siswi setelah mendapatkan penyuluhan kesehatan menggunakan metode brain storming dan simulation game pada post test sebagian besar pengalami peningkatan tingkat pengetahuan baik manjadi 51 siswi (70,83\%), tingkat pengetahuan cukup menjadi 21 siswi $(29,17 \%)$, tidak ada yang memiliki tingkat pengetahuan kurang.

4. Terdapat perbedaan efektivitas yang signifikan antara penyuluhan kesehatan menggunakan metode brain storming dan simulation game dalam meningkatkan pengetahuan siswi mengenai kanker payudara dengan signifikasi value 0,000 .

\section{DAFTAR PUSTAKA}

1. Kementerian Kesehatan RI. Bulan Peduli Kanker Payudara, Oktober 2016. Pusat Data dan Informasi, Jakarta. 2016

2. Kementerian Kesehatan RI. Stop Kanker, 4 Februari-Hari Kanker Sedunia. Pusat Data dan Informasi, Jakarta. 2015.

3. Dona. Gambaran Pengetahuan Mahasiswi Angkatan Tahun 2009 Fakultas Ekonomi USU Medan Tentang Kanker Payudara Dan SADARI. Fakultas Kedokteran Universitas Sumatra Utara. Online[WWW]. 2011. http://repository.usu.ac.id/bitstre am/handle/123456789/31363/C over.pdf?sequence $=7$ \&isAllowe $\mathrm{d}=\mathrm{y}$. [accessed 10 Juni 2018].

4. Sari, Rini Mulia. Hubungan Pengetahuan dan Sikap Dengan Risiko Kanker Payudara Pada Remaja Putri Di MAN 2 Banda Aceh. Tugas Akhir. Tidak Diterbitkan. Universitas Ubudiyah Indonesia. Banda Aceh. 2012.

5. Notoadmodjo, S. Promosi Kesehatan dan Perilaku Kesehatan. 2012. Jakarta: Rineka Cipta.

6. Notoadmodjo, S. Promosi Kesehatan dan Perilaku Kesehatan. 2012. Jakarta: Rineka Cipta.

7. Diniar, Oki Resna. Pengaruh Pendidikan Kesehatan Tentang Pencegahan Kanker Payudara Terhadap Peningkatan Pengetahuan Dan Sikap Wanita Usia Produktif di Desa Sumur Musuk Boyolali. Online [WWW]. 2013.

http://eprints.ums.ac.id/27205/1/ HALAMAN DEPAN.pdf. [accessed 15 April 2019].

8. Vitro, Rizanda, dan Yenita. Faktor-Faktor Yang Berhubungan Dengan Tingkat Pengetahuan Wanita Usia Subur Tentang SADARI Di Nagari Painan. Online [WWW]. 2016.

http://jurnal.fk.unand.ac.id/index .php/jka/article/view/604/490. [accessed 15 April 2019].

9. Notoadmodjo, S. Promosi Kesehatan dan Perilaku Kesehatan. 2007. Jakarta: Rineka Cipta. 
10. Mubarak dan Wahid. Promosi Kesehatan Sebuah Pengantar Praktik Belajar Mengajar dalam Pendidikan. 2007. Yogyakarta: Graha IImu

11. Donggori, Ratna Indriana. Hubungan Akses Media Massa Dengan Pengetahuan Kesehatan Reproduksi Pada Remaja. Fakultas Kedokteran Universitas Diponegoro. Online [WWW]. 2012.

https://eprints.undip.ac.id. [accessed 23 April 2019].

12. Notoadmodjo, S. Promosi Kesehatan dan Perilaku Kesehatan. 2012. Jakarta: Rineka Cipta.

13. Pratama, Laras Ayunda. Efektifitas Pendidikan Kesehatan Terhadap Nilai Pengetahuan Mengenai SADARI Pada Remaja Putri di SMPN 3 Tangerang Selatan. Online $\quad$ [WWW]. 2014. http://repository.uinjkt.ac.id/dsp ace/bitstream/123456789/2558 2/1/Laras\%20Ayunda\%20Prata ma\%20-\%20fkik.pdf. [accessed 1 Mei 2019].

14. Maryam, Siti. Promosi Kesehatan Dalam Pelayanan Kebidanan. 2014. Jakarta:EGC.

15. Andi, Buraerah, dan Mulyani. Pengaruh Metode Simulasi Permainan dan Brainstorming Terhadap Pengetahuan dan Sikap Pengurus PKI-R SMA Tentang Kesehatan Reproduksi
Remaja Di Kota Makassar.

Online [WWW]. 2013.

https://repository.unhas.ac.id. [accessed 10 Mei 2019].

16. Departemen Kesehatan RI, Pusat Promosi Kesehatan, Panduan Pelatihan Komunikasi Perubahan Perilaku, KIBBLA, Jakarta 2008.

17. Rehalat, Aminah. Model Pembelajaran Pemrosesan Informasi. Online [WWW]. 2014. http://ejournal.upi.edu>article>vi ewFile>Pdf. [accessed 1 Juni 2019].

18. Notoadmodjo, S. Promosi Kesehatan dan Perilaku Kesehatan. 2007. Jakarta: Rineka Cipta.

19. Notoadmodjo, S. Promosi Kesehatan dan Perilaku Kesehatan. 2012. Jakarta: Rineka Cipta.

20. Affandi, B. Pelatihan Keterampilan Melatih. 2003. Jakarta: Jaringan Nasional Pelatihan Klinik-Kesehatan Reproduksi.

21. Notoadmodjo, S. Promosi Kesehatan dan Perilaku Kesehatan. 2010. Jakarta: Rineka Cipta.

22. Qolby, Bunayya Syifa. Uji Mann Whitney Dalam Statistika Non Parametrik Perbedaan Tingkat Pengqunaan Kendaraan Umum Dengan Kendaraan Pribadi. Online [WWW]. 2014. https://www.academia.edu. [accessed 1 Juni 2019] 